\title{
TEMPORAL VARIATIONS OF POLLUTANT LOADS DURING STORM EVENTS IN A SMALL RIVER BASIN
}

\author{
T. Fujiwara ${ }^{*}$, A. Yoshida ${ }^{* *}$ and K. Ohtoshi* \\ "Faculty of Agriculture, Kochi University, 200 Monobe Otsu, Nankoku, Kochi 783-8502, Japan \\ (E-mail: fujiwara@ee.kochi-u.ac.jp) \\ ${ }^{* *}$ YONDEN CONSULTANTS CO.,INC, Azouno Nakamachi 7-21, Kochi 781-0013, Japan
}

\begin{abstract}
Not only to estimate the impact of storm water on receiving waters but also to deduce the origin of the pollutants, it is important to analyze the runoff characteristics of pollutants during storm events. We conducted seven surveys during storm events to clarify the runoff characteristics of various pollutants and relationships between pollutant loads and runoff patterns. In addition, origins of various ions were deduced by examining the temporal variations of ion composition. Typical first flush effects in VSS and T-BOD concentrations were observed, and it was estimated that river sediments deposited in fine days strongly affect the runoff of VSS during a storm event. $\mathrm{NO}_{3}{ }^{-} \mathrm{N}$ concentration decreased by the early runoff, but kept up higher level at the recession stage, while ion concentrations decreased during the rising stage and increased again at the recession stage, indicating that ions were diluted by the major runoff. Relationships between pollutant loads and runoff were examined by the empirical equation " $L / A=a(Q / A)^{n}$ ". Judging from the $\mathrm{n}$

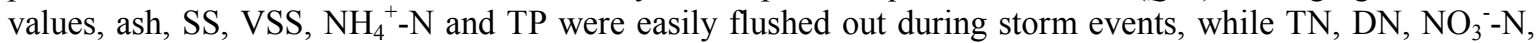
$\mathrm{K}^{+}$and DOC kept almost constant concentration during a storm event. Most ions seemed to be diluted by storm water. It was indicated that $\mathrm{NO}_{3}^{-}, \mathrm{SO}_{4}{ }^{2-}$ and $\mathrm{K}^{+}$were mainly originated from diffuse sources during storm events in the surveyed watershed, while $\mathrm{Mg}^{2+}$ and $\mathrm{Na}^{+}$was from the same source as $\mathrm{Cl}^{-}$. Most of the nitrate and sulfate loads seemed to be drained out from the surface soil layer of river basins and carried by subsurface runoff.
\end{abstract}

\section{KEYWORDS}

First flush effect, Ion composition, Pollutant loads, Small river basin, Storm events, Temporal variation,

\section{INTRODUCTION}

Pollutant loading from the storm water runoff has been identified as one of the major causes of deterioration of the quality of receiving water bodies. Runoff characteristics of pollutants differ widely, depending on their origin and runoff behavior in transit. Therefore, analysis of the characteristics is important not only to estimate the impact of storm water on receiving waters but also to deduce the origin of the pollutants. Patrick et al. (Patrick et al., 2002) characterized stormwater runoff loads and concentrations of 10 common constituents and analyzed effects of season and land use. They also propose the predictive models of stormwater runoff volumes, loads and pollutant concentrations from watershed. Ana (Ana, 1998) analyzed evidence for the existence and nature of the first flush load of pollution input into drainage systems, using data of storm surface runoff. Ralf (Ralf, 2001) clarified rainfall-induced sediment and pesticide input from orchards into a river. Gregory et al. (Gregory et al., 2005) estimated the fraction of organisms associated with settleable particles in stormwater. Many other researchers (Rimer et al. 1978; Ebise et al.,1982;Lee et al., 2000) have investigated the pollutant loads for many constituents during storm events. We also clarified the runoff characteristics of pollutants during a rising stage of the river flow precisely with many water quality indices observed in a small river basin through principal component analysis (Fujiwara et al., 2002). In many previous works, however, only a few water quality indices were observed during stormwater runoff and few researchers analyzed the change in ion composition during storm events to deduce the origins of those. 
This study aims to clarify the runoff characteristics of various pollutants during storm events and relationships between pollutant loads and runoff patterns, and to analyze the first flush effect. In addition, origins of various ions are deduced by examining the temporal variations of ion composition. Seven storm events were surveyed in a small river basin during the period from October 2000 to November 2003. Flow rate and 29 water quality indices such as biochemical oxygen demand (BOD), suspended solids (SS), volatile suspended solids (VSS), total nitrogen (TN), nitrate nitrogen $\left(\mathrm{NO}_{3}{ }^{-} \mathrm{N}\right), \mathrm{SO}_{4}{ }^{2-}, \mathrm{Na}^{+}, \mathrm{Cl}^{-}$, among others, were observed for the analysis of storm water runoff.

\section{MATERIALS AND METHODS}

\section{Site description}

Fig.1 shows the Uji River basin investigated in this study. The river is a tributary of Niyodo River and is located in Ino town, the central part of Kochi prefecture, Japan. The area of watershed is $14.7 \mathrm{~km}^{2}$ and the mainstream length is $7.5 \mathrm{~km}$. Forests, residential districts and agricultural fields account for $76 \%, 13 \%$ and $11 \%$ of the watershed, respectively. Residential districts shown as the shaded portion in Fig. 1 are located around the junction of Uji River and Tenjindani River, and around the downstream area of Saina River. Paddy fields, the dotted portion in the figure, are located around the midstream area of Uji River and around the junction of Uji River and Niyodo River. There are many pulp factories around the downstream area of Saina River, and the wastewater from the factories is discharged into Saina River. The wastewater has high concentration of particulate organic compounds but low concentrations of nitrogen, phosphorus, and ions. According to our periodical observations once a week or two weeks from June 7 to December 13 in 2000, the average T-BOD concentration at Ekiminami of Saina River was as high as $10 \mathrm{mg} / \mathrm{L}$. In addition, the average T-BOD loading at the same point was $24.5 \%$ of that at Sunagamori about $400 \mathrm{~m}$ downstream from junction of Uji River and Saina River. Domestic sewage except night soil is directly discharged into the rivers in most areas of the watershed. A lot of particulate organic compounds are expected to be deposited in fine days due to not only the slow flow velocity of the river, but the high concentration of particulate organic compounds in effluent from factories or residential districts. These river sediments seem to be flushed out during storm events.

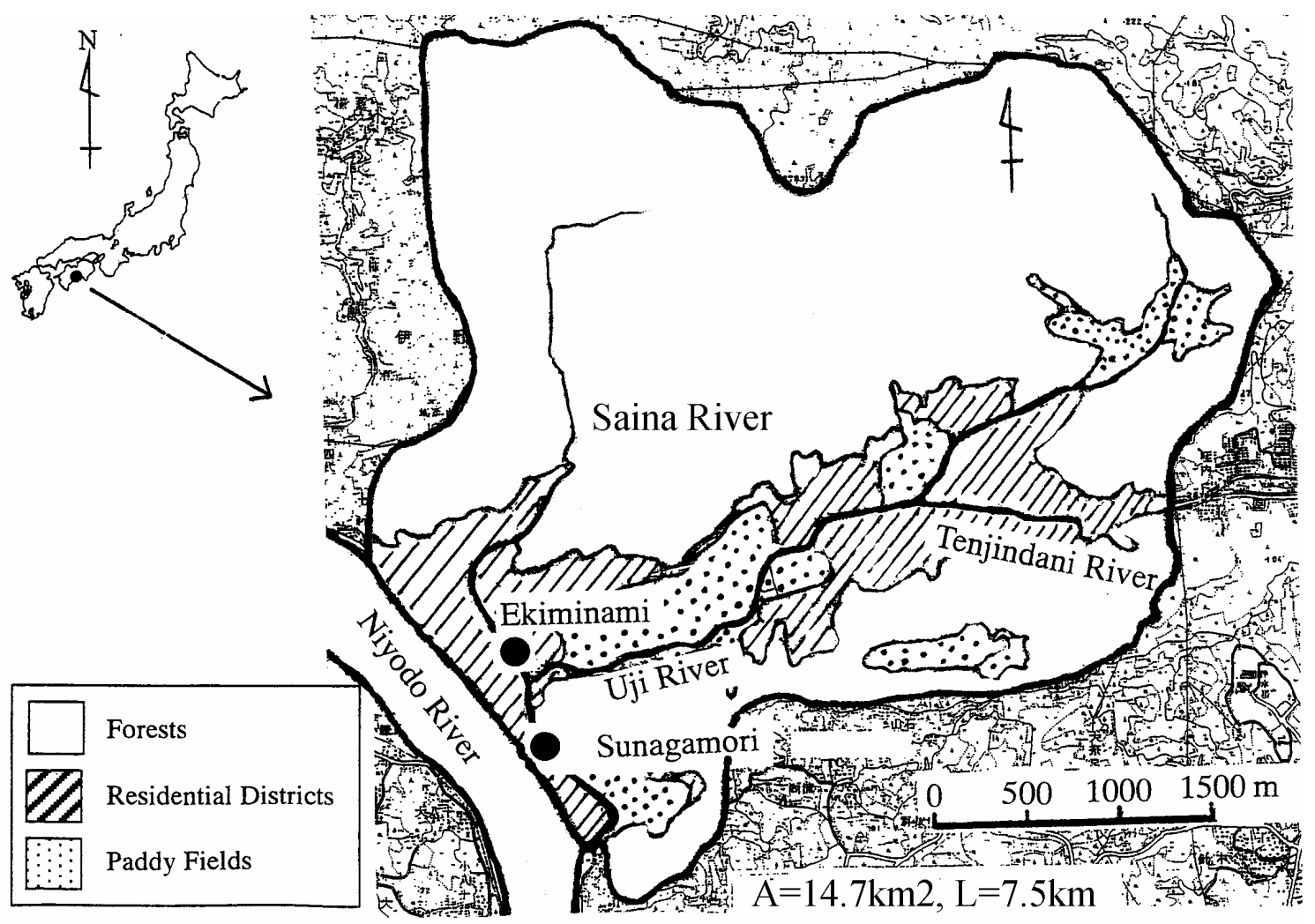

Fig.1 Surveying watershed 


\section{Sampling and analysis}

Seven storm events were surveyed at Sunagmaori shown in Fig.1 from October 2000 to December 2003. Duration and hydrological condition in each survey are listed in Table 1. Total precipitation during the survey ranged from $15 \mathrm{~mm}$ to $186 \mathrm{~mm}$ and the preceding precipitation in the $2^{\text {nd }}$ survey was as much as 160 $\mathrm{mm} / 10$ days. Both the rising stage and the recession stage of the river flow were observed except the $1^{\text {st }}$ survey. In the $3^{\text {rd }}$ and $4^{\text {th }}$ survey, the authors surveyed the second and the third storm event out of the series of three storm events.

Sampling was conducted at approximately 15-60 minutes intervals for rising flow stage and 1- 24h intervals for recession flow stage. The samples were transported to the laboratory and filtered through $1 \mu$ $\mathrm{m}$ glass fiber filters (Whatman GF/B). The water quality indices analyzed are summarized in Table 2. Water temperature (W.T.), pH, DO, ORP, EC were measured on site. The other analyses were performed in

Table 1 Characteristics of each survey

\begin{tabular}{|c|c|c|c|c|}
\hline $\begin{array}{l}\text { Number of } \\
\text { the survey }\end{array}$ & Duration of the survey & $\begin{array}{c}\text { Precipitation } \\
\text { during the survey }\end{array}$ & $\begin{array}{c}\text { Sum of the preceding } \\
\text { precipitation }\end{array}$ & Remarks \\
\hline 1 & Oct. $9^{\text {th }} 10: 00-24: 00(2000)$ & $75 \mathrm{~mm}$ & $65 \mathrm{~mm} / 10$ days & During the rising stage \\
\hline 2 & 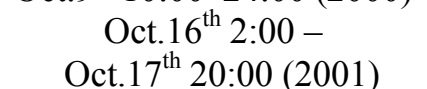 & $105 \mathrm{~mm}$ & $160 \mathrm{~mm} / 10$ days & \\
\hline 3 & $\begin{array}{l}\text { Sep. } 15^{\text {th }} 14: 00- \\
\text { Sep.16 } \\
\text { Se:00 (2002) }\end{array}$ & $21 \mathrm{~mm}$ & $16 \mathrm{~mm} / 10$ days & $\begin{array}{c}2^{\text {nd }} \text { storm out of the series } \\
\text { of } 3 \text { storm events }\end{array}$ \\
\hline 4 & $\begin{array}{c}\text { Sep. } 16^{\text {th }} 6: 00-\text { Sep. } 17^{\text {th }} \\
20: 00(2002)\end{array}$ & $33 \mathrm{~mm}$ & $37 \mathrm{~mm} / 10$ days & $\begin{array}{c}3^{\text {rd }} \text { storm out of the series } \\
\text { of } 3 \text { storm events }\end{array}$ \\
\hline 5 & $\begin{array}{c}\text { Apr. } 29^{\text {th }} 18: 00- \\
\text { May. } 2^{\text {th }} 12: 00(2003)\end{array}$ & $15 \mathrm{~mm}$ & $40 \mathrm{~mm} / 10$ days & \\
\hline 6 & $\begin{array}{c}\text { July } 17^{\text {th }} 23: 00- \\
\text { July } 21^{\text {st }} 9: 00(2003)\end{array}$ & $95 \mathrm{~mm}$ & $64 \mathrm{~mm} / 10$ days & \\
\hline 7 & $\begin{array}{l}\text { Nov. } 27^{\text {th }} 16: 00- \\
\text { Dec. } 5^{\text {th }} 11: 00(2003)\end{array}$ & $186 \mathrm{~mm}$ & $24 \mathrm{~mm} / 10$ days & \\
\hline
\end{tabular}

Table 2 Water quality indices and their analytical methods

\begin{tabular}{|c|c|c|}
\hline Index & Unit & Method \\
\hline W.T. & ${ }^{\circ} \mathrm{C}$ & EC Meter (TOA, CM-21P) \\
\hline $\mathrm{pH}$ & - & pH Meter (TOA, HM-12P) \\
\hline DO & $\mathrm{mg} / \mathrm{L}$ & Membrane electrode method $(* 4500 \mathrm{O}-\mathrm{G})(\mathrm{TOA}, \mathrm{DO}-21 \mathrm{P})$ \\
\hline ORP & $\mathrm{mV}$ & Oxidation-Reduction Potential measurement in clean water $(* 2580 \mathrm{~B})$ (TOA, HM-14P) \\
\hline EC & $\mathrm{mS} / \mathrm{m}$ & EC Meter (TOA, CM-21P) \\
\hline SS & $\mathrm{mg} / \mathrm{L}$ & Total suspended solids dried at $103-105^{\circ} \mathrm{C}(* 2540 \mathrm{D})$ \\
\hline & & Filters of $1.0 \mu \mathrm{m}$ nominal pore size (Whatman $\mathrm{GF} / \mathrm{B}$ ) were used. \\
\hline Ash & $\mathrm{mg} / \mathrm{L}$ & 3 -hr ignition at $400^{\circ} \mathrm{C}$ of a filter used for determination of SS. \\
\hline VSS & $\mathrm{mg} / \mathrm{L}$ & Difference between SS and Ash \\
\hline T, D-BOD & $\mathrm{mg} / \mathrm{L}$ & 5 -Day BOD Test $(* 5210-B)$ \\
\hline TOC, DOC & $\mathrm{mgC} / \mathrm{L}$ & High-temperature combustion method $(* 5310-\mathrm{B})($ Shimazu TOC-5000A) \\
\hline TN, DN & $\mathrm{mgN} / \mathrm{L}$ & $\begin{array}{l}\text { Persulfate method ( } 4500-\mathrm{N} \mathrm{C}) \text { and automated cadmium reduction method }\left(* 4500-\mathrm{NO}_{3}{ }^{-} \mathrm{F}\right) \\
\text { (Bran+Luebbe AACS II ) }\end{array}$ \\
\hline $\mathrm{NO}_{3}{ }^{-}-\mathrm{N}$ & $\mathrm{mgN} / \mathrm{L}$ & Automated cadmium reduction method $\left(* 4500-\mathrm{NO}_{3}{ }^{-} \mathrm{F}\right)(\mathrm{Bran}+$ Luebbe AACS II $)$ \\
\hline $\mathrm{NO}_{2}-\mathrm{N}$ & $\mathrm{mgN} / \mathrm{L}$ & Colorimetric method $\left(* 4500 \mathrm{NO}_{2}{ }^{-} \mathrm{B}\right)($ Bran+Luebbe AACS II $)$ \\
\hline $\mathrm{NH}_{4}{ }^{+}-\mathrm{N}$ & $\mathrm{mgN} / \mathrm{L}$ & Automated phenate method $\left(* 4500-\mathrm{NH}_{3} \mathrm{G}\right)($ Bran+Luebbe AACS II $)$ \\
\hline TP, DP & $\mathrm{mgP} / \mathrm{L}$ & $\begin{array}{l}\text { Persulfate digestion and automated ascorbic acid reduction method }(* 4500-\mathrm{P} F) \\
\text { (Bran+Luebbe AACS II ) }\end{array}$ \\
\hline $\mathrm{PO}_{4}{ }^{3-}-\mathrm{P}$ & $\mathrm{mgP} / \mathrm{L}$ & Automated ascorbic acid reduction method (*4500-P F) (Bran+Luebbe AACS II ) \\
\hline $\mathrm{Na}^{+}, \mathrm{K}^{+}$ & $\mathrm{mg} / \mathrm{L}$ & Determination of cations by Ion Chromatography (Dionex DX-120) \\
\hline $\mathrm{Ca}^{2+}, \mathrm{Mg}_{2-}^{2+}$ & & Cation separator column: Dionex CS12A, Eluent solution: $20 \mathrm{mM}$ methanesulfonic acid \\
\hline $\mathrm{Cl}^{-}, \mathrm{SO}_{4}{ }^{2-}$ & $\mathrm{mg} / \mathrm{L}$ & Determination of anions by Ion Chromatography $(* 4110)$ (DionexDX-120) \\
\hline $\mathrm{F}^{-}, \mathrm{Br}^{-}$ & & Anion separator column: Dionex AS12A, Eluent solution: $2.7 \mathrm{mM} \mathrm{Na}_{2} \mathrm{CO}_{3} / 0.3 \mathrm{mM} \mathrm{NaHCO}_{3}$ \\
\hline $\mathrm{HCO}_{3}^{-}$ & $\mathrm{mg} / \mathrm{L}$ & Equivalent by alkalinity, Alkalinity: Titration method $(* 2320 \mathrm{~B})$ \\
\hline
\end{tabular}

Analytical methods are numbered in Standard Methods for the examination of water and wastewater. 
the laboratory in accordance with the official methods (APHA, AWWA and WEF; 1998). T-BOD, TOC, T-N and T-P were analyzed with samples which were not filtered. The other indices were determined with samples after filtration.

\section{RESULTS AND DISCUSSIONS}

\section{Temporal variations of water quality}

The results for the $2^{\text {nd }}$ and $7^{\text {th }}$ survey are shown in Fig. 2 and Fig.3 to give examples of the surveys. The concentration peaks for VSS and T-BOD, which occurs before the flow peak, was caused by the early runoff, flushing the pollutants accumulated in fine days from the riverbed. It was noted from the curbs of Fig.3 that typical first flush effects in concentrations, which has been observed by other investigators (Rimer et al.,1978; Lee et al., 1996, Lee et al., 2000), occurred for storm events. The peak concentrations of VSS and T-BOD at $1: 30$ on November $28^{\text {th }}$ in 2003 , were as high as $50.5 \mathrm{mg} / \mathrm{L}$ and $24.2 \mathrm{mg} / \mathrm{L}$, respectively. River flow rate at the time was $0.55 \mathrm{~m}^{3} / \mathrm{s}$ and precipitation just before the concentration peaks was $11 \mathrm{~mm} / 3 \mathrm{hrs}$. On the other hand, sharp concentration peaks were not observed during the $2^{\text {nd }}$ survey as shown in Fig.2. Although river flow rate of $0.93 \mathrm{~m}^{3} / \mathrm{s}$ at the concentration peak and precipitation of $9 \mathrm{~mm} / 3 \mathrm{hrs}$ just before the peak were nearly the same with those in $7^{\text {th }}$ survey, the peak concentrations of VSS and T-BOD were as low as $11.8 \mathrm{mg} / \mathrm{L}$ and $6.0 \mathrm{mg} / \mathrm{L}$, respectively. Because the preceding precipitation was much more in the $2^{\text {nd }}$ survey, most of the deposited pollutants in fine days seemed to have been flushed out during that precipitation. Similarly, low peak concentrations (VSS $=13.5 \mathrm{mg} / \mathrm{L}$ and $\mathrm{T}-\mathrm{BOD}=4.3 \mathrm{mg} / \mathrm{L}$ ) were observed in the $4^{\text {th }}$ survey in which the third storm out of the series of three storm events was surveyed. Most of the pollutants were judged to have flushed out in the first and second storm events. Except for the $2^{\text {nd }}$ and $4^{\text {th }}$ survey, sharp concentration peaks were observed in all surveys and measured peak of VSS and T-BOD concentration ranged from $14.9 \mathrm{mg} / \mathrm{L}$ to $62.8 \mathrm{mg} / \mathrm{L}$ and from $8.5 \mathrm{mg} / \mathrm{L}$ to $28 \mathrm{mg} / \mathrm{L}$, respectively.
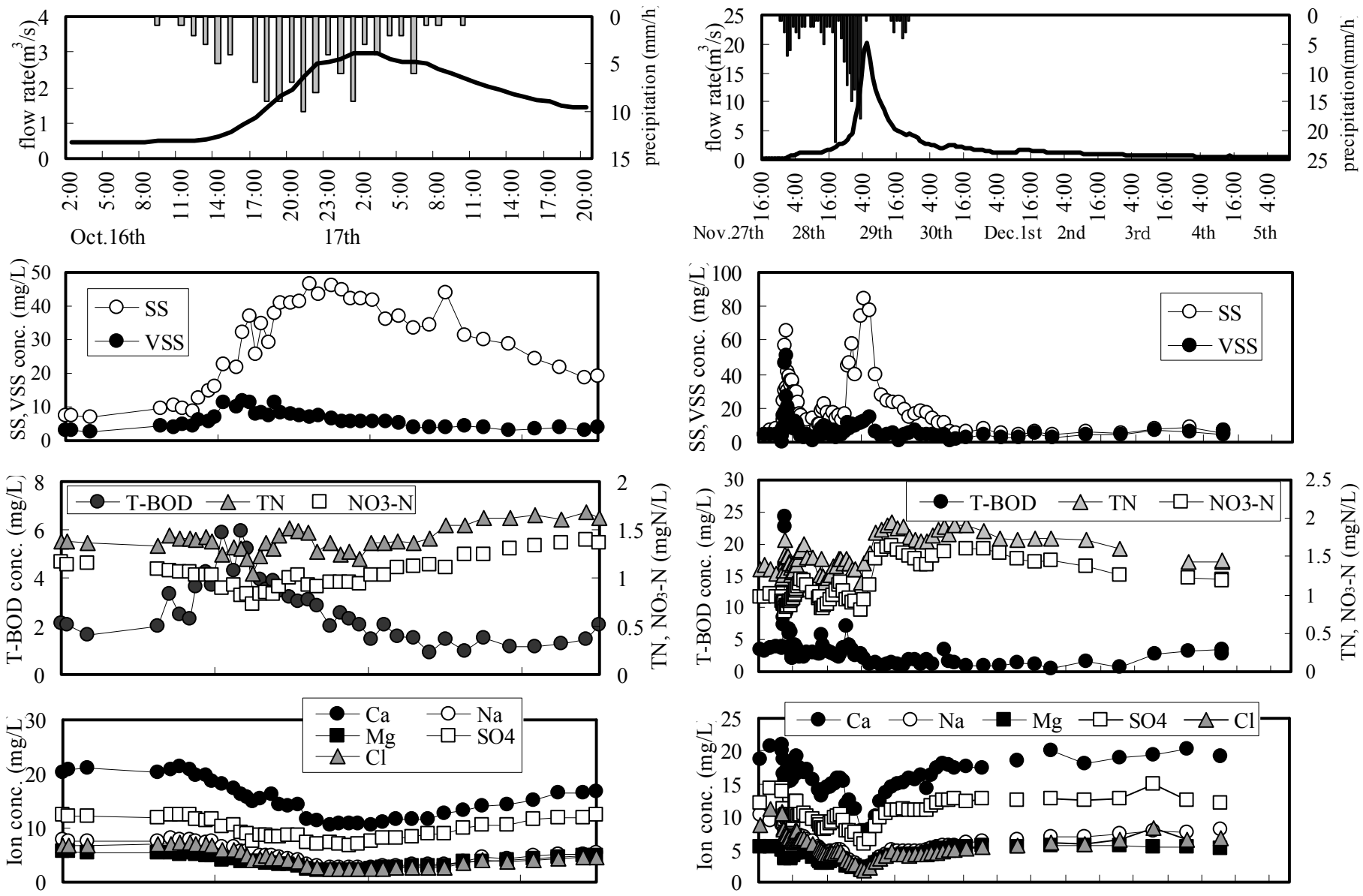

Fig.2 Time courses of precipitation, flow rate and water quality ( $2^{\text {nd }}$ survey)
Fig.3 Time courses of precipitation, flow rate and water quality ( $7^{\text {th }}$ survey) 

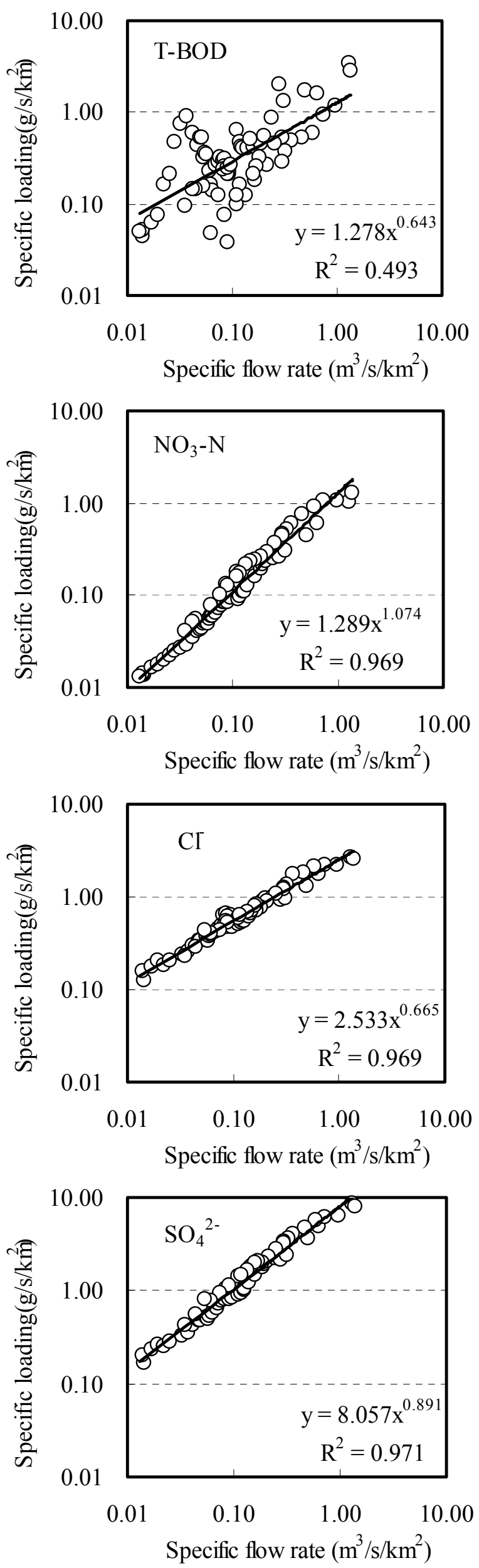

Fig.4 relationships between specific loading and specific flow rate $\left(7^{\text {th }}\right.$ survey)

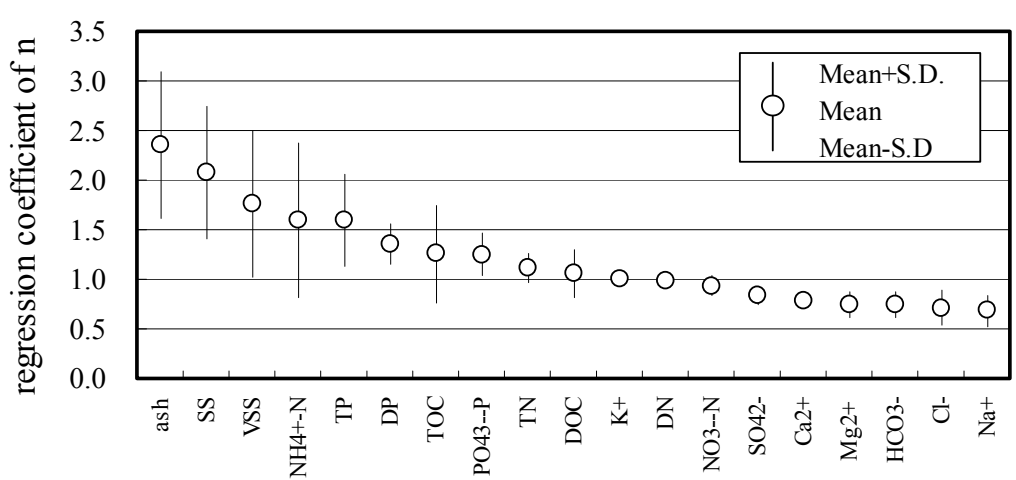

Fig.5 regression coefficient of $\mathrm{n}$ for each constituent

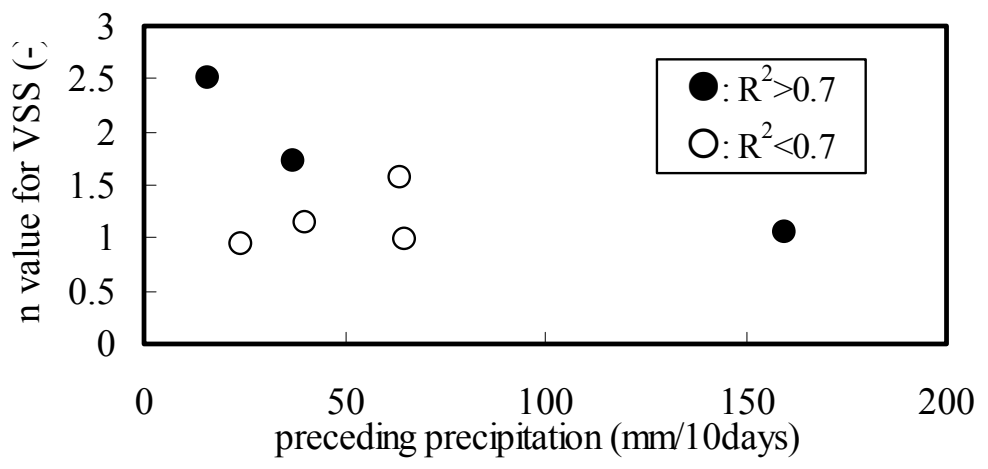

Fig.6 relationship between $n$ value for VSS and preceding precipitation

$\mathrm{NO}_{3}{ }^{-}-\mathrm{N}$ concentration decreased by the early runoff, but gradually increased and kept up higher level at the recession stage. Other researcher also observed these phenomena (Ebise et al.,1982). Ion concentrations decreased during the rising stage and increased again at the recession stage, indicating that ions were diluted by the major runoff.

\section{Relationships between pollutant load and flow rate}

Relationships between pollutant loads and runoff are examined by the following empirical equation.

$$
L / A=a(Q / A)^{n}
$$

In which $L$ is pollutant load $(\mathrm{g} / \mathrm{s}), A$ is watershed area $\left(\mathrm{km}^{2}\right), Q$ is river flow rate $\left(\mathrm{m}^{3} / \mathrm{s}\right)$ and $a$ and $n$ are regression coefficients. Fig.4 shows the relationships between the load and runoff for selected constituents in the $7^{\text {th }}$ survey. Because typical first flush effects were observed in T-BOD concentration, the regression line has poor agreement for T-BOD. The regression lines for most constituents such as $\mathrm{NO}_{3}{ }^{-} \mathrm{N}, \mathrm{Cl}^{-}$and $\mathrm{SO}_{4}{ }^{2-}$ have good agreement as shown in the figure. Generally, runoff characteristics of pollutants are evaluated by the regression coefficient of $\mathrm{n}$ as shown below.

$\mathrm{n}>1$ : flushing

$\mathrm{n}=1$ : constant concentration $\mathrm{n}<1$ : dilution 
Fig.5 demonstrates the runoff characteristics of each constituent. If coefficient of determination for the regression line is less than 0.7 , the authors omit the regression coefficients from this analysis. Four and six out of seven coefficients are omitted for VSS and T-BOD, respectively, because of the first flush effect. As shown in Fig.5, the average values of $\mathrm{n}$ for ash, SS, VSS, $\mathrm{NH}_{4}{ }^{+}-\mathrm{N}$ and TP are more than 1.5, indicating that these constituents are easily flushed out during storm events. Fig.6 shows the relationship between $n$ value for VSS and preceding precipitation. As shown in the figure, the more preceding precipitation becomes, the lower $\mathrm{n}$ value is calculated. This result implies that river sediments deposited in fine days strongly affect the runoff of VSS during a storm event. Fig.5 also shows that the average values of $\mathrm{n}$ for $\mathrm{TN}, \mathrm{DN}^{-} \mathrm{NO}_{3}{ }^{-}-\mathrm{N}$, $\mathrm{K}^{+}$and DOC are around 1.0. This result indicates that these constituents keep almost constant concentration during a storm event. Most ions seem to be diluted by storm water. The averages of $\mathrm{n}$ value for $\mathrm{Cl}^{-}$and $\mathrm{Na}^{+}$ are as low as 0.71 and 0.68 , respectively. This result indicates that these ions are strongly affected by point sources such as domestic sewage. The fact that domestic sewage except night soil is directly discharged into the rivers in most areas of the watershed supports this deduction.

\section{Temporal variations of ion composition}

Temporal variations of ion composition during storm events are examined. Fig.7 and Fig.8 show relationships between flow rate and ion composition in $2^{\text {nd }}$ and $7^{\text {th }}$ survey, respectively. As shown in the figures, both $\mathrm{NO}_{3}{ }^{-} / \mathrm{Cl}^{-}$and $\mathrm{SO}_{4}{ }^{2-} / \mathrm{Cl}^{-}$equivalent ratio rose with the increase of flow rate, while $\mathrm{Na}^{+} / \mathrm{Cl}^{-}$ equivalent ratio kept nearly constant during storm events. As mentioned above, $\mathrm{Cl}^{-}$seems to be strongly affected by point sources such as domestic sewage. Therefore, this result indicates that $\mathrm{NO}_{3}{ }^{-}$and $\mathrm{SO}_{4}{ }^{2-}$ are mainly originated from diffuse sources during storm events in the surveyed watershed, while $\mathrm{Na}^{+}$is from point sources. These figures also demonstrate that $\mathrm{NO}_{3}{ }^{-} / \mathrm{Cl}^{-}$and $\mathrm{SO}_{4}{ }^{2-} / \mathrm{Cl}^{-}$equivalent ratio during recession stage are higher than those during rising stage. This fact implies that most of the nitrate and sulfate loads
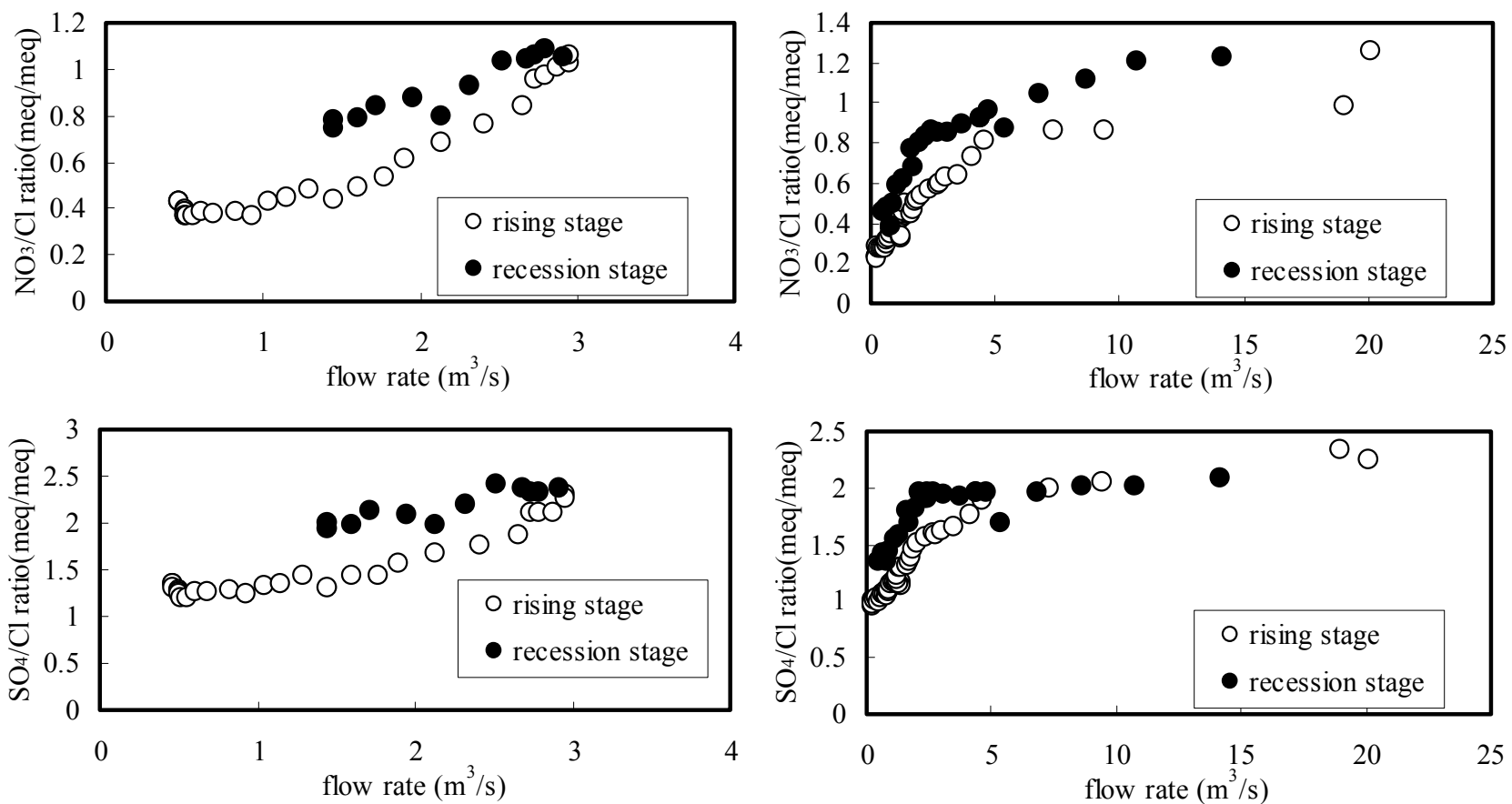

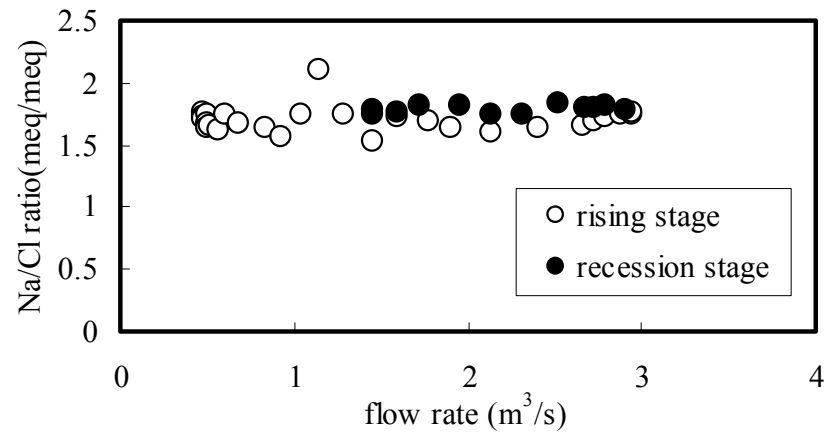

Fig.7 Relationships between flow rate and ion composition ( $2^{\text {nd }}$ survey)

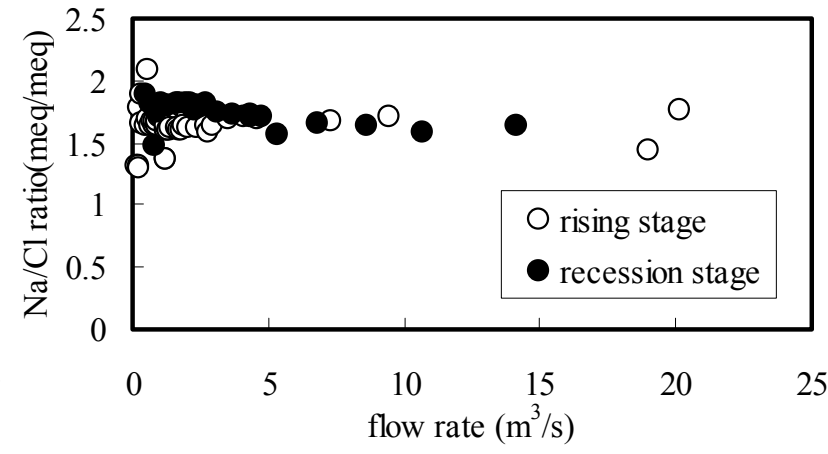

Fig.8 Relationships between flow rate and ion composition ( $7^{\text {th }}$ survey) 


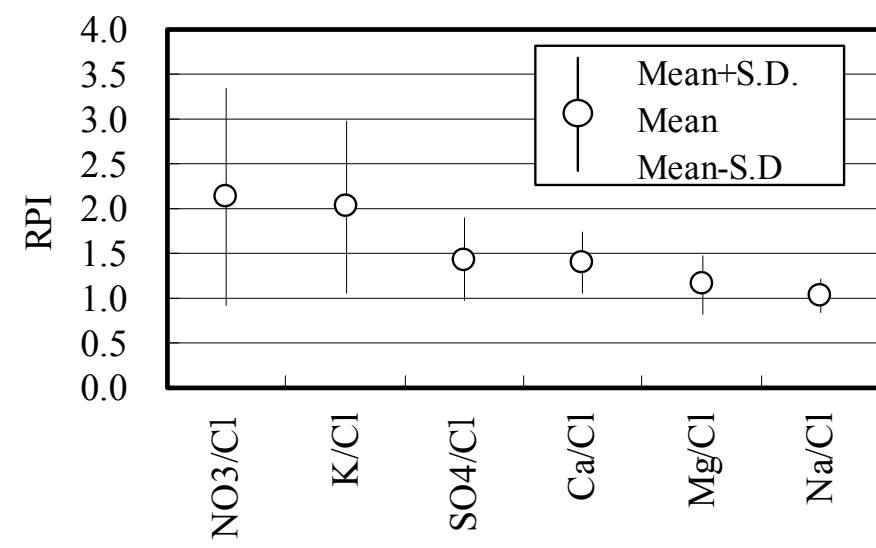

Fig.9 RPI for various ions

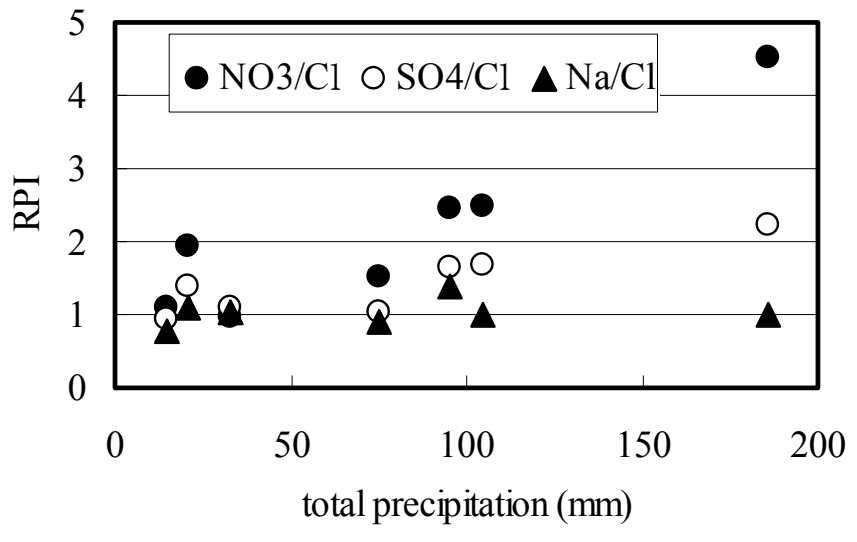

Fig.10 Relationships between RPI and total precipitation

are drained out from the surface soil layer of river basins and carried by subsurface runoff.

To analyze the change in ion composition accompanied with the increase of flow rate, the following index is defined.

$$
\mathrm{RPI}=([\mathrm{A}] /[\mathrm{Cl}])_{\mathrm{P}} /([\mathrm{A}] /[\mathrm{Cl}])_{\mathrm{I}}
$$

Where, $[\mathrm{A}]$ is the concentration of ion " $\mathrm{A}$ " (meq/L), $[\mathrm{Cl}]$ is the $\mathrm{Cl}^{-}$concentration $(\mathrm{meq} / \mathrm{L}),([\mathrm{A}] /[\mathrm{Cl}]) \mathrm{P}$ and $([\mathrm{A}] /[\mathrm{Cl}])_{\mathrm{I}}$ are $[\mathrm{A}] /[\mathrm{Cl}]$ ratio at the flow peak and at the initial condition, respectively. Fig.9 gives the RPI for various ions. This result indicates that $\mathrm{NO}_{3}{ }^{-}$and $\mathrm{K}^{+}$are strongly affected by diffuse sources during storm events in the surveyed watershed, while $\mathrm{Mg}^{2+}$ and $\mathrm{Na}^{+}$are mainly discharged by the same source as $\mathrm{Cl}^{-}$. Fig.10 shows the relationships between RPI and total precipitation. RPI for $\mathrm{NO}_{3}^{-} / \mathrm{Cl}^{-}$and $\mathrm{SO}_{4}{ }^{2-} / \mathrm{Cl}^{-}$ increase with total precipitation, while RPI for $\mathrm{Na}^{+} / \mathrm{Cl}^{-}$keeps almost 1 for all storm events. This result supports the deduction for the origins of these ions mentioned above.

\section{CONCLUSIONS}

Seven storm events were surveyed in a small river basin to clarify the runoff characteristics of various pollutants during storm events and relationships between pollutant loads and runoff patterns. In addition, origins of various ions were deduced by examining the temporal variations of ion composition. The following results are obtained:

(1) Except for the $2^{\text {nd }}$ and $4^{\text {th }}$ survey in which most of the pollutants had been flushed out from the riverbed during the preceding precipitation, sharp concentration peaks of VSS and T-BOD were observed in all surveys and the measured peak concentration ranged from $14.9 \mathrm{mg} / \mathrm{L}$ to $62.8 \mathrm{mg} / \mathrm{L}$ and from $8.5 \mathrm{mg} / \mathrm{L}$ to $28 \mathrm{mg} / \mathrm{L}$, respectively.

(2) $\mathrm{NO}_{3}{ }^{-}-\mathrm{N}$ concentration decreased by the early runoff, but gradually increased and kept up higher level at the recession stage. Ion concentrations decreased during the rising stage and increased again at the recession stage, indicating that ions were diluted by the major runoff.

(3) Relationships between pollutant loads and runoff were examined by the empirical equation " $L / A=a$ $(Q / A)^{n}$ ". Judging from the $\mathrm{n}$ values, ash, $\mathrm{SS}, \mathrm{VSS}, \mathrm{NH}_{4}{ }^{+} \mathrm{N}$ and $\mathrm{TP}$ were easily flushed out during storm events, while TN, DN, $\mathrm{NO}_{3}{ }^{-}-\mathrm{N}, \mathrm{K}^{+}$and DOC kept almost constant concentration during a storm event. Most ions seemed to be diluted by storm water.

(4) The more preceding precipitation became, the lower n value for VSS was calculated. Hence, it was estimated that river sediments deposited in fine days strongly affected the runoff of VSS during a storm event.

(5) Origins of various ions were deduced by examining the temporal variations of ion composition. As a result, it was indicated that $\mathrm{NO}_{3}{ }^{-}, \mathrm{SO}_{4}{ }^{2-}$ and $\mathrm{K}^{+}$were mainly originated from diffuse sources during storm events in the surveyed watershed, while $\mathrm{Mg}^{2+}$ and $\mathrm{Na}^{+}$was from the same source as $\mathrm{Cl}^{-}$. In addition, most of the nitrate and sulfate loads seemed to be drained out from the surface soil layer of river basins and carried by subsurface runoff. 


\section{ACKNOWLEDGEMENT}

We would like to thank Ms. Risa Inukai, Mr. Masamitsu Ikebe, Mr. Takaaki Doi and Mr. Daisuke Hagiwara for their support for this work. We are also grateful to the financial support by Charitable trust wastewater management research promotion fund.

\section{REFERENCES}

Ana Deletic (1998). The first flush load of urban surface runoff, Water Research, 32 (8), 2462-2470

Ebise S., Muraoka K. and Otubo K. (1982). Separation of run-off components by water quality, Proceedings of the 26th Japanese conference on Hydraulics, 21, 279-284

Fujiwara T., Ohtoshi K., Ishikawa R. and Ikebe M. (2002). Runoff characteristics of pollutants from a small river basin during a rising stage of river flow, Advances in Asian Environmental Engineering, 2 (2), 1-7

Lee J. H., Bang K. W. and Lee J. K. (1996). A study of runoff characteristics of pollutants in combined sewer overflow. J. Korean Soc. Environ. Eng. 18(10), 1147-1160

Lee J. H. and Bang K. W. (2000). Characterization of urban stormwater runoff, Water Research, 34 (6), 1773-1780.

Patrick L. B. and Teresa H. S. (2002). Analysis and predictive models of stormwater runoff volumes, loads, and pollutant concentrations from watersheds in the Twin Cities metropolitan area, Minnesota, USA, Water Research, 36 (7), 1743-1757

Ralf Schulz (2001). Rainfall-induced sediment and pesticide input from orchards into the lourens river, western cape, south africa: importance of a single event, Water Research, 35 (8), 1869-1876

Rimer A. E., et al. (1978). Characterization and impact of storm water runoff from various land cover types. J. Water Pollut. Control Fed., 252-264

Standard Methods for Examination of Water and Wastewater (1998). 20 th edition, American Public Health Association / American Water Works Association / Water Environment Federation, Washington DC, USA. 